\title{
Identification and Analysis of Stunting Risk Factors in Children under Three Years of Age in the Area of Kampar Watershed
}

\author{
Riski Novera Yenita ${ }^{1 *(D)}$, Thamrin Thamrin² ${ }^{2}$ Bintal Amin ${ }^{3}$, Agrina Agrina $^{4}$ \\ ${ }^{1}$ Department of Public Health, STIKes Al-Insyirah, Doctoral Student on Program of Environmental Science, Universitas Riau, \\ Pekanbaru, Indonesia; ${ }^{2}$ Department of Environmental Science, Doctoral Program of Environmental Science, Universitas Riau, \\ Pekanbaru, Indonesia; ${ }^{3}$ Department of Marine Science, Universitas Riau, Pekanbaru, Indonesia; ${ }^{4}$ Department of Nursing, \\ Faculty of Nursing, Universitas Riau, Pekanbaru, Indonesia
}

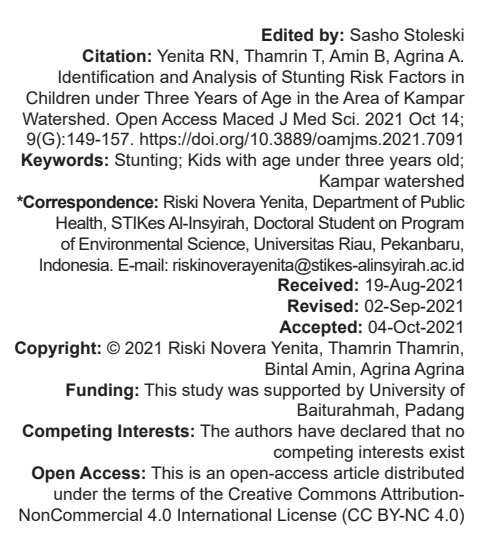

\begin{abstract}
BACKGROUND: Growth and development that are not optimal are a form of chronic malnutrition, one of which is marked by height for age which is below the standard deviation $(<-2 \mathrm{SD})$ and is called stunting. Stunting has a negative impact on children's motor development, reduces children's performance in school, increases the risk of excess nutrition, infectious diseases, and even death as well as reduces productivity in adulthood.

AIM: The purpose of this study was to identify risk factors for stunting in people living in the Kampar watershed.

METHODS: This research is a mixed-method with an explanatory sequential design which is a modification of. The research was carried out on people living in the Kampar river basin. The priority areas for specific stunting reduction interventions in this study are the Work Areas of the Kampar Kiri Hulu II Health Center, the Koto Kampar XIII Health Center, and the Kampar Kiri Health Center.

RESULTS: This study found that the dominant factors of the five variables were home sanitation and parenting, as both affected the incidence of stunting. The findings obtained are different from the results of data analysis obtained from interviews, observations, and descriptive statistics.

CONCLUSION: Based on the results of data analysis from interviews, observations, and descriptive statistics, it was found that all variables of the three factors became the main factors that had a close relationship with the incidence of stunting in the community in the Kampar watershed.
\end{abstract}

\section{Introduction}

Failure to grow and develop optimally early in life is still a health problem that can be found in almost all corners of the world, especially concerning the economic sector. Delayed growth and development is a form of chronic malnutrition characterized by height for the age that is below the standard deviation $(<-2 \mathrm{SD})$ or what is often known as stunting [1], [2]. [3], [4]. Stunting or low height for the age of 12-24 months is caused by inadequate nutritional intake and frequent occurrence of infections. Stunting has a negative impact on children's motor development, reduces performance at school, increases the risk of overnutrition, infectious diseases, and even death in addition to reducing productivity in adulthood. The period after birth that is prone to lack of linear growth is after 3-6 months to 24-36 months [5].

In the WHO hearing, it was stated that hygiene is the main factor for reducing the risk of stunting in children under five [6]. Environmental factors that are not well maintained are still experiencing a significant increase in various countries. In 2016, there were $22.9 \%$ or 154.8 million children under the age of
5 years experiencing stunting. In the same year, as many as 87 million children in Asia were also recorded to be stunted, followed by 59 million children in Africa and 6 million in Latin America and the Caribbean. Five states also have child stunting rates that exceed $(30 \%)$ namely West Africa (31.4\%), Central Africa (32.5\%), East Africa (36.7\%), South Asia (34.1\%), Oceania (38.3\%), excluding Australia and New Zealand [7].

In 2013, it was found that more than one-third $(37 \%)$ of children in Indonesia aged $<5$ years were stunted with a prevalence exceeding (40\%) in 15 of the 33 provinces in Indonesia. If you look back, the data obtained in the Basic Health Research (2010) inform that the prevalence of stunted toddlers continues to increase, especially in the 12-23 month age group. The increase occurred from $(28.1 \%)$ in the age group $<5$ months, too $(32.1 \%)$ in the age group $6-11$ months, and increase to $(41.5 \%)$ in the age group 12-23 months Riau et al. [8], Torlesse et al. [9] states that there are three districts in Indonesia with a stunting prevalence of $28.4 \%$ and severe stunting of $6.7 \%$. Goodarz [10] adds that there are 18 modifiable risk factors for stunting, namely: Nutrition and infection in mothers, adolescence maternal and short birth spacing, delay in fetal growth, 
premature birth, nutritional status of children, parenting, infection, and environmental factors. Environmental factors, in this case, include poor sanitation, lack of clean water availability, and the use of biomass fuel in the household. The global priority of health development in the 2015-2019 national medium-term development plan (RPJMN) is nutrition improvement, particularly in the form of efforts to reduce stunting prevalence. Problems related to stunting cannot be solved only through nutrition programs but must be integrated with other programs. Rokan Hulu and Kampar regencies as known are two regencies out of 160 regencies/cities in Indonesia as priority areas (special locations) for stunting handling in 2018 and 2019 as determined by the National Team for Poverty Reduction (TNP2K).

Data obtained from basic health research in 2013 and 2018 in Riau Province recorded a decrease in the prevalence of stunting in children under five by $9.4 \%$, from $36.8 \%$ to $27.4 \%$. However, the incidence of stunting increased again to 16,275 children under five in 2019. The target of the 2019 RPJMN is to reduce the prevalence of stunting to $28 \%$. Until 2020 , five districts are special locations for handling stunting interventions in Riau, including Rokan Hulu, Kampar, Meranti, Siak, and Rokan Hilir. Following the Decree of the Minister of National Development Planning on Determining the Location of the Intervention Focus for Reducing Stunting Integration in 2020-2021, the location, in this case, is Kampar Regency. Therefore, this study aims to identify risk factors for stunting in communities in the Kampar river basin.

\section{Materials and Methods}

The type of this research is a mixed-method with an explanatory sequential design which is a modification of [1], [2], [3]. This research was carried out on people living in the Kampar river basin, where the priority areas for special stunting reduction interventions were the Work Area of the Kampar Kiri Hulu II Health Center, Koto Kampar XIII Health Center, Kampar Kiri Health Center. Sampling was done using the judgmentor criteria sampling technique with the criteria set by the researcher. The inclusion criteria for the sample were: (1) Children had a Healthy Card book, (2) Toddlers with a nutritional status below the red line, and (3) Mothers with an incomplete history of antenatal visits. The following is the sample calculation process based on the criteria set by previous researchers:

This study focused on environmental factors (clean water and home sanitation, economic factors (parents' income and food security), and social factors (parenting patterns). This study conducted interviews, observations, surveys by researchers, accompanied by the distribution of questionnaires through direct mentoring. Key informants are mothers who have children under the age of 3 years who are identified as stunting where the factors studied are home sanitation and clean water sources, parents' income, food, and parenting patterns.

\section{Results}

Identification of stunting status plays a role in determining children under 3 years of age who are indicated to be stunted. Of the 141 samples assigned (Table 1), there were 112 children with short growth $(79.4 \%)$ and 29 children with very short growth (20.6\%). Identification of stunting in terms of gender found that the majority of stunting sufferers in children under 3 years were male as presented in Table 2 .

Table 1: Sampling

\begin{tabular}{ll}
\hline Criteria & Total \\
Population & 552 Toddlers \\
Criteria 1: Not owning Card to Health book & 311 Toddlers (-) \\
Pass Criteria 1 & 241 Toddlers \\
Criteria 2: Toddler with nutrition status under Red Line & 50 Toddlers (-) \\
Pass Criteria 2 & 191 Toddlers \\
Criteria 3: The mother who does not have Pregnancy Visit history & 50 Toddlers (-) \\
Total Samples & 141 Toddlers \\
\hline
\end{tabular}

The majority of boys under 3 years of age were identified as stunting, indicating that there was an influence of sex on stunting status. This finding is supported by studies conducted by Song [11], Garenne et al. [12], Akombi et al. [13], Wamani et al. [14] which found that boys were more likely to be stunted than girls. However, this is also contrary to previous research conducted by Biswas and Bose [15], Candra et al. [16], Lourenço et al. [17] where there was no relationship between the sex of the child and the incidence of stunting.

Table 2: Distribution of identification of stunting status by health center and gender

\begin{tabular}{llll}
\hline Area & Male & Female & Total \\
\hline Public Health Center Koto Kampar & 24 & 20 & 44 \\
Public Health Center Kampar Kiri & 51 & 29 & 80 \\
Public Health Center Kampar Kiri Hulu II & 13 & 4 & 17 \\
Total & 87 & 54 & 141 \\
\hline
\end{tabular}

The majority of stunting in boys can be influenced by other factors, such as parenting, mother's education, mother's height, history of exclusive breastfeeding, history of complementary feeding, history of infection, and history of immunization [11]. The following information is stunting status based on the child's age with a maximum age limit of 3 years, namely:

Based on Table 3, it can be further explained that the majority of children identified as stunted were those aged between 25 and 36 months which reached more than $65 \%$, namely, 92 children. This shows that external influences that play a major role in the incidence of stunting are environmental factors [18], [19], economic factors [20], and social factors [21], [22], [23]. 
Table 3: Distribution of stunting status identification based on stunting child age and gender

\begin{tabular}{llll}
\hline Public health center & Male & Female & Total \\
\hline Koto Kampar & & & \\
$0-12$ months & 8 & 4 & 12 \\
13-24 months & 6 & 15 & 25 \\
$25-36$ months & 10 & 20 & 44 \\
$\quad$ Total & 24 & 2 & 3 \\
Kampar Kiri & 1 & 2 & 24 \\
$0-12$ months & 22 & 25 & 53 \\
$13-24$ months & 28 & 29 & 80 \\
$25-36$ months & 51 & 2 & 2 \\
Total & 0 & 0 & 0 \\
Kampar Kiri Hulu II & 0 & 2 & 15 \\
$0-12$ months & 13 & 4 & 17 \\
13-24 months & 13 & & \\
$25-36$ months & & & \\
Total & & & \\
\hline
\end{tabular}

Furthermore, information about the Z-score aims to identify the highest stunting case value that occurred in the three Health Centers. This information is presented in Table 4.

Table 4: Identification of stunting status based on the Z-score

\begin{tabular}{llll}
\hline Calculating of stunting status & \multicolumn{3}{l}{ Public health center } \\
\cline { 2 - 4 } & Koto Kampar & Kampar Kiri & Kampar Kiri Hulu II \\
\hline Average Z-score & -2.57 & -2.65 & -2.75 \\
Average Z-score Male & -2.84 & -2.67 & -2.77 \\
Average Z-score Female & -2.46 & -2.61 & -2.34 \\
The highest Z-score & -3.81 & -5.22 & -3.93 \\
The lowest Z-score & -2.03 & -2.03 & -2.03 \\
Gender & Male & Female & Male \\
The Highest Z-score & & & \\
\hline
\end{tabular}

Referring to Table 4, it can be seen that the Kampar Kiri Hulu II Health Center has the highest average Z-score of -2.75 , the Kampar Kiri Health Center of -2.65 , and the Koto Kampar Health Center of -2.57 . If you look at the value based on the Standard Height according to age based on the Regulation of the Minister of Health of the Republic of Indonesia No. 2 of 2020, all children under 3 years of age from the three Health Centers identified as Stunting experienced height growth which was included in the short standard. The highest Z-score value of the three Health Centers was -5.22 at the Kampar Kiri Health Center, -3.91 at the Kampar Kiri Hulu II Health Center, and -3.83 at the Koto Kampar Health Center. The highest Z-score value of the three Health Centers was -5.22 at the Kampar Kiri Health Center, namely, for children under the age of three who were female. Seeing the above conditions, the gender factor cannot be classified as a predictor of stunting.

Other findings obtained from interviews and observations made by researchers while at the research location is the determining factors for determining that children under the age of 3 years who are identified as stunting are not only height growth factors, but there are other factors. Researchers found that some children under the age of three who were identified as stunted had intelligence, motor, sensory, and response to the treatment or treatment given by the researcher. The treatment given by the researcher is communication, calling the child's name, seeing the child's interaction with other people, and asking questions that are appropriate for the child's age. Researchers, in this case, observe the response given during the treatment process.
Research by Walker et al. [24], Khomsan et al. [25], Perignon et al. [26] shows that children's intelligence has a relationship with stunting, meaning that children identified as stunted have lower intelligence than non-stunted children. These results can be seen from the number of children under the age of three who were identified as stunted having a good motor, sensory, and response to the treatment given by the researcher. This is in line with the findings [24], [27], [28], [29] which found that stunting factors can affect the motor, sensory, and response development of children.

\section{Discussion}

Environmental factors are one of the aspects that affect the growth and development process of toddlers and provide a risk for stunting. Poor environmental sanitation will have an indirect impact on the health of toddlers which, in turn, can affect their nutritional status. Research that says that these environmental factors greatly affect the incidence of stunting, among others, is research by Kusumawati et al. [4], Beal et al. [30], Kwami et al. [31], Sutarto et al. [32], Rahayu et al. [33], Utami et al. [34]. The distribution of clean water supply in the study area shows that 87 households $(61.7 \%)$ do not meet the requirements and only 54 households $(38.3 \%)$ meet the requirements for clean water supply. This amount is presented in the distribution Table 5:

Table 5: Frequency distribution of clean water supply

\begin{tabular}{|c|c|c|c|}
\hline \multirow[t]{2}{*}{ Distribution } & \multicolumn{3}{|c|}{ Public health center } \\
\hline & Koto Kampar & Kampar Kiri & $\begin{array}{l}\text { Kampar Kir } \\
\text { Hulu II }\end{array}$ \\
\hline \multicolumn{4}{|c|}{ Water sources for household need in cooking } \\
\hline Pump & 22 & 17 & 9 \\
\hline Dug well & 5 & 22 & 4 \\
\hline Refill water depot & 17 & 41 & 4 \\
\hline \multicolumn{4}{|c|}{ Water sources used by other households } \\
\hline Yes & 27 & 31 & 10 \\
\hline No & 17 & 39 & 7 \\
\hline \multicolumn{4}{|l|}{ Water color } \\
\hline Clear & 2 & 13 & 5 \\
\hline A bit turbid & 42 & 67 & 12 \\
\hline \multicolumn{4}{|l|}{ Water taste } \\
\hline Bid & 42 & 73 & 15 \\
\hline Not bid & 2 & 7 & 2 \\
\hline \multicolumn{4}{|l|}{ Water smell } \\
\hline Smelly & 2 & 6 & 2 \\
\hline Not smelly & 42 & 74 & 15 \\
\hline Total & 44 & 80 & 17 \\
\hline
\end{tabular}

Based on Table 5, it can be explained that the water source used by the majority of residents who have children under 3 years of age identified Stunting at the Koto Kampar Health Center and the Kampar Kiri Hulu II Health Center is a pump well. On the other hand, the majority of the Kampar Kiri Community Health Center uses refill water depots. The water sources used by other households indicate that the majority of the community of the Koto Kampar Health Center and the Kampar Kiri Hulu II Health Center are not used by other households and vice versa, that the majority of the Kampar Kiri Health Center is used by other households. Regarding the color of the water in the water source 
used by residents who have children under 3 years of age and was identified as stunted in the three health centers, the majority of which were slightly cloudy in color. Regarding the taste of water, the majority of them have a bland taste. Meanwhile, the majority of the water used is odorless.

The information above shows that the majority of residents at the Kampar Kiri Health Center use the same water source. To see further these findings, further testing was carried out on the quality of clean water used by residents who have children under 3 years of age and identified as stunting. This information presents the distribution of clean water supply used by residents for sanitation purposes.

The house sanitation factor is an important factor in the incidence of stunting. One of the steps to prevent stunting is to implement a Clean and Healthy Lifestyle (PHBS) by every household by increasing access to clean water and sanitation facilities, as well as maintaining environmental cleanliness. PHBS reduces the incidence of illness, especially infectious diseases that can divert energy for growth to the body's resistance to infection, the difficulty of the body to absorb nutrients, and stunted growth. The sanitation factor at the location of residents' homes with children under 3 years of age identified as stunted showed that 104 households $(73.8 \%)$ did not meet the requirements and only 37 households (26.2\%) met the sanitation requirements for healthy homes. The distribution of household sanitation in the research location is presented in Table 6:

Table 6: Frequency distribution of house sanitation criteria

\begin{tabular}{|c|c|c|c|}
\hline \multirow[t]{2}{*}{ Distribution } & \multicolumn{3}{|c|}{ Public health center } \\
\hline & Koto Kampar & Kampar Kiri & Kampar Kiri Hulu II \\
\hline \multicolumn{4}{|l|}{ Garbage dump } \\
\hline Trash can/hole & 37 & 83 & 15 \\
\hline Littering & 7 & 7 & 2 \\
\hline \multicolumn{4}{|l|}{ Channel of waste water } \\
\hline Available & 23 & 67 & 16 \\
\hline Unavailable & 21 & 13 & 1 \\
\hline \multicolumn{4}{|l|}{ The condition of water channel } \\
\hline Open & 25 & 52 & 12 \\
\hline Closed & 19 & 28 & 5 \\
\hline \multicolumn{4}{|l|}{ Smoothness of waste water channel } \\
\hline Smooth & 31 & 62 & 14 \\
\hline Not Smooth & 13 & 18 & 3 \\
\hline \multicolumn{4}{|l|}{ Yard free of farm animal dung } \\
\hline Yes & 28 & 52 & 16 \\
\hline No & 16 & 28 & 1 \\
\hline \multicolumn{4}{|l|}{ Yard is frequently clean } \\
\hline Yes & 40 & 76 & 17 \\
\hline No & 4 & 4 & - \\
\hline \multicolumn{4}{|l|}{$\begin{array}{l}\text { The distance between cattle pen and } \\
\text { the house }\end{array}$} \\
\hline$\geq 10 \mathrm{~m}$ & 23 & 58 & 10 \\
\hline$<10 \mathrm{~m}$ & 21 & 22 & 7 \\
\hline \multicolumn{4}{|l|}{ Source of clean water } \\
\hline Dug well & 4 & 36 & 5 \\
\hline Artesian well & - & 6 & - \\
\hline $\begin{array}{l}\text { PDAM (Local Company of Drinking } \\
\text { Water) }\end{array}$ & 40 & 38 & 12 \\
\hline \multicolumn{4}{|l|}{$\begin{array}{l}\text { Distance between waste disposal and } \\
\text { water source }\end{array}$} \\
\hline$\geq 10 \mathrm{~m}$ & 22 & 50 & 11 \\
\hline$<10 \mathrm{~m}$ & 21 & 30 & 6 \\
\hline Total & 44 & 80 & 17 \\
\hline
\end{tabular}

Referring to Table 6 , it can be seen that the garbage disposal sites in the homes of residents who have children under 3 years of age and identified as stunted, the majority are following clean sanitation requirements where they dispose of waste in its place.
For sewerage, the majority of them already have sewerage. The condition of the sewerage in the houses of residents who have children under 3 years of age identified as stunted is mostly open. The smooth flow of wastewater is included into smooth category. The yards of residents who have children under 3-yearsold and identified as Stunting, the majority of them are free from livestock manure. Furthermore, regarding the cleanliness of the yard, the majority of residents' houses with children under 3 years of age identified as stunted are in the clean category. The distance between the cattle pens and the houses of most of the residents is more than $10 \mathrm{~m}$. As for the source of clean water, they have a water source that comes from PDAM. The distance from the waste disposal to the water source in the houses of residents who have children under 3-years-old identified as stunted, mostly more than $10 \mathrm{~m}$

Of the nine indicators in the clean house sanitation assessment, those that are said to have met the requirements are open water channels, the majority of which are owned by the homes of residents who have children under 3 years of age identified as stunting. Thus, it can be said that of these nine indicators, the majority of each household has one indicator that does not meet the sanitation requirements of a clean house so that it is categorized as a house that has unqualified sanitation.

Poor environmental sanitation is closely associated with stunting in toddlers. Therefore, the improvement of environmental sanitation is very necessary to prevent the occurrence of health problems in children under five that are likely to affect their nutritional status [9], [35], [36]. Poor environmental sanitation conditions, unhealthy drinking water, and unhygienic behavior are one of the factors that cause diarrhea in infants or toddlers. Diarrhea disease that is continuous or occurs repeatedly in infants/toddlers will cause malnutrition. This occurs as a result of damage to the intestinal mucosa by fecal bacteria which results in impaired absorption of nutrients [36].

Economic factors are the dominant factors that cause stunting in children under 3 years of age. Economic factors are strongly influenced by the level of family income. Disrupted food access at the household level is mainly caused by poverty which in turn gives rise to malnutrition, one of which is stunting. Information obtained regarding family income shows that 97 households $(68.8 \%)$ have a family income (UMR - regional minimum wage) that meets the criteria for decent and only 44 households (31.2\%) do not meet the criteria for the UMR in Kampar Regency in 2020, IDR. 2,950,088.00.

Past research, on the other hand, concluded that family income had nothing to do with the number of stunting events. High family income does not guarantee a reduction in stunting, but stunting can be reduced if the income can be allocated to provide nutritious food 
for children under the age of three [20]. This could be because the income received is not fully spent on basic food needs, but for other needs. A high level of income does not necessarily guarantee good nutritional status for children under five, because the level of income is not necessarily allocated adequately for food purposes. If families with low incomes can manage nutritious food with simple and inexpensive ingredients, the baby's growth will also be good.

In addition, food security is the main factor to ensure that children under 3 years of age consume nutritious food for the whole family. Information on food availability for families as a food security factor is presented in Table 7.

Table 7: Food availability

\begin{tabular}{llll}
\hline Area & Available & Unavailable & Total \\
\hline Public Health Center Koto Kampar & 26 & 18 & 44 \\
Public Health Center Kampar Kiri & 47 & 33 & 80 \\
Public Health Center Kampar Kiri Hulu II & 9 & 8 & 17 \\
Total & 82 & 59 & 141 \\
\hline
\end{tabular}

From Table 7, it can be explained that the majority of households in the working areas of the three health centers have sufficient food availability for their families. This condition indicates that households with children under 3 years of age can meet the food needs of their families. In addition, supporting information was also obtained from field observations conducted by researchers through interviews with key informants, namely, residents or mothers who have children under 3 years of age and identified as stunting. The information obtained relates to the ability of parents in terms of economic factors to meet the needs of nutritious food. Information obtained from interviews with AG informants from the Koto Kampar Health Center is as follows:

"Apabila dari segi penghasilan, kami mampu memenuhi kebutuhan makan, anak saya sudah cukup makan tiga kali sehari, tetapi kalau soal gizi atau empat sehat lima sempurna, bagi saya tidak terlalu penting, yang terpenting adalah anak saya mau makan" (Bahasa Indonesia).

"In terms of income, we can meet the needs of food, three meals a day is enough for my child, but when it comes to nutrition, for me it is not too important, the most important thing is that my child has a good appetite" (English version).

Based on the interview excerpt above, it is clear that the AG informant who has children under the age of three who were identified as stunted has a clean water source that does not meet the standards and thinks that nutritious food is not important. For her, the most important thing is that her child eats 3 times a day. Economically, the informant felt that she was able to fulfill her food needs, but she did not think much about the nutrition of the food provided. Other information from OKT informants from the Kampar Kiri Hulu II Health Center can be summarized as follows:

"Apabila ditanya soal penghasilan, saya tidak bisa menyebutkannya, tetapi kalau anak ibu, dia itu sulit mau makan, walaupun ibu kasih dia makan, kadang ibu buat telur dadar, tetapi dia tetap tidak mau makan, ditambah anak ibu suka sekali jajan-jajan, ibu berpikir itu sudah cukup, dan yang terpenting dia tidak sakit perut." (Bahasa Indonesia).

"When asked about income, I cannot mention it. My child is a child whose appetite is not good. Even though I give my kid food, sometimes an omelet, he still won't eat. Besides that, he likes snacking a lot, I think that's enough, and most importantly he doesn't have a stomach ache" (English version).

The interview excerpt above illustrates that OKT who have children under 3 years of age and are identified as stunted with clean water sources that do not meet standards do not have knowledge of nutritious food and awareness of the importance of nutritious food for the developmental phase of children under 3 years of age. The information obtained from the two informants is almost the same, namely the absence of parental knowledge about nutritious food and awareness to provide their children with nutritious food. Economically, parents cannot ensure that they meet their nutritional needs. However, for real food, and parents can suffice. To corroborate this information, the researcher conducted interviews with NA who represented the Kampar Kiri Health Center. Here's an excerpt of the interview:

"Dari segi penghasilan, saya tidak bisa memastikan, kalau kekurangan mungkin iya tetapi bisa jadi tidak karena dicukup-cukupkan, alhamdulillah, anak saya tidak mau makan, dia suka jajan saja, kadangkadang saya berikan ikan hasil pancingan, tetapi tetap anak kami suka makan jajan, yang terpenting, anak kami ada makan dan tidak sakit perut" (Bahasa Indonesia).

"In terms of income, I can't say for sure, if the income is low, it might be because the income is not adjusted properly, but thank God. My son has a low appetite, he just likes snacking. Sometimes I give fish from fishing, but our son still prefers snacking. Most importantly, there is food that our child wants to eat and no stomach ache" (English version).

Based on the interview excerpt above, it is clear that NA who has children under 3 years of age identified as stunted with clean water sources that do not meet standards has lack of good knowledge about nutritious food and awareness of the importance of nutritious food for the developmental phase of children under 3 years of age year. From an economic perspective, they can still meet their food needs, but not with nutrition. From the three informants interviewed, it can be concluded that parents who have children under 3 years of age identified as stunted in a simple economic condition, meaning that they are only able to meet food needs but cannot ensure that the food provided is nutritious or not. This condition is supported by the lack of knowledge and awareness of parents about the importance of 
nutritious food. Even though the economic factors of parents already earn above the minimum wage, the knowledge and awareness of parents who have not been maximized on the importance of nutritious food is the main factor to prevent stunted children.

However, Rohmawati [37], Budiastutik and Nugraheni [38], Phyo et al. [39] found different results where it was concluded that family income was the dominant factor determining the incidence of stunting. Families with low incomes are relatively only able to use limited health services. Low incomes have an impact on low purchasing power so that it is difficult to get access to adequate food. As a result, the quality, quantity, and variety of food consumed are also low, especially foods for child growth and development such as sources of protein, vitamins, and minerals [4]. Families with low economic levels tend to allocate their income for needs other than food, so that family nutrition is not the main thing to be met [40].

In addition to the factors of low quality and quantity and variety of food, the factor of the number of children who grow up in poor families is the most vulnerable to malnutrition. This is due to a larger allocation of food with a higher amount of food needs so that it will affect the child's stunting rate. More specifically, if a family consists of many children, then the food for each child will decrease and many parents do not realize that very young child need more food than older ones [37]. The number of household members is an important element in preventing short or chronic malnutrition [41].

Parenting is the main behavioral aspect in the incidence of stunting, especially in the provision of food to children. Parenting is a pattern of parental behavior applied to children that are relative and consistent from time to time. Parenting patterns describe how parents treat children, educate, guide, and discipline children in reaching the maturity process to the effort of forming norms expected by society in general. The magnitude of the influence of parenting on the incidence of stunting makes parenting a major factor in this study. The frequency distribution of parenting factors shows that 94 households $(66.7 \%)$ have poor parenting and only 47 households (33.3\%) have good parenting so that stunting can be prevented.

Additional information obtained from interviews and observations at the research site was used to dig deeper information about parenting applied by parents of children under 3-years-old who were identified as stunting. The information obtained serves to see and describe the actual parenting in the field. The topic of the interview with the informant was parenting in children. Information obtained from interviews with $A G$ informants from the Koto Kampar Health Center is as follows:

"kalau anak kami beri kebebasan dalam berbuat, anak kami laki-laki, pasti badannya kuat, kami tidak melarang apa yang dilakukannya, tidak mempertanyakan apa yang dilakukannya, begitu juga dengan makan, kalau dia lapar, pasti dia akan nyari makan, terserah dia mau makan apa, yang penting makan" (Bahasa Indonesia).

"We free our son to act. He is a boy and he must have a strong body. We do not easily forbid anything he does and do not question what he does, as well as eating. If he is hungry, he will surely get the food. It's up to him what he wants to eat, the important thing is he should eat" (English version).

Based on the interview excerpt above, it can be further explained that $A G$ who has children under 3-years-old who are identified as stunted has a permissive parenting pattern. In other words, this can be interpreted as a pattern of parental behavior in interacting with children that frees children to do what children want without asking permission from parents. Other information comes from OKT who is an informant from the Kampar Kiri Hulu II Health Center as follows:

"Anak kami laki-laki, pasti fisiknyo kuat, kami serahkan saja kepada anak apa yang mau dilakukan, lain pula rasanya kalau anak laki-laki dilarang, untuk makan pun, kami terserah anak, yang penting makan" (Bahasa Indonesia).

"Our son is a boy, he must be physically strong. We believe in everything our children want to do. It would be different if a boy was given the word "don't" too often to do what he wanted. Regarding eating, it's all up to him, the important thing is that he eats" (English version).

Based on the interview excerpts, it is clear that OCT who have children under 3-years-old who are identified as stunted have permissive parenting conditions or can be interpreted as a pattern of parental behavior in interacting with children that frees children to do what they want to do without questioning. This condition is the same with AG. Other information comes from NA who is an informant from the Kampar Kiri Health Center as follows:

"Anak kami laki-laki, pasti fisiknyo kuat, main dengan teman-temannya, tidak kami larang, main di tempat lain dari rumah pun, kami tidak banyak tanya, untuk hal makan pun, yang terpenting dia mau makan, itu saja udah cukup" (Bahasa Indonesia).

"Our son is a boy, he must be physically strong. We let him play with his friends. They play in other places outside the house too and it is okay. Regarding eating, the most important thing is that he wants to eat, that's enough" (English version).

The interview excerpt above provides information that NA who has children under the age of three who are identified as stunted has a permissive parenting condition which can be interpreted as a pattern of parental behavior that frees children to do whatever the child wants to do without questioning. This 
condition is the same as the two previous informants who were the risk factors for stunting.

This is in line with several studies. Research Pebriani et al. [21], Aini et al. [22], Arsyad [23] stated that in their study, parents were not involved in child-rearing, or they were permissive or always discussed with children, they tended to provide food according to the child's emotional state. Parents who are not involved in childcare also tend to provide food as a way to regulate children's behavior and do not control children's food. This permissive parenting pattern triggers the increasing incidence of stunting. However, other research results contradict this finding. Krisnana [42] stated that parenting did not have a relationship with the level of stunting.

Analysis of the risk factors causing stunting derived from questionnaire data, interviews, and observations on stunting risk factors was environmental factors with the variables of clean water supply and house sanitation, economic factors with family income and food availability variables, and social factors with parenting variables. These three factors are important for the incidence of stunting in the working areas of the three health centers. To convince the researchers, statistical testing was carried out using logistic regression. The results of the logistic regression test are presented in Table 8.

\section{Table 8: Statistical testing}

\begin{tabular}{llll}
\hline & B & Df & Significant \\
\hline Testing Value & -1.308 & 1 & 0.000 \\
Step & -2 Log likelihood & Cox and Snell R Square & Nagelkerke R Square \\
1 & 131.217 & 0.099 & 0.154 \\
\hline Hosmer and Lemeshow Test & & \\
\hline Step & Chi-square & Df & Significant \\
\hline 1 & 3.670 & 7 & 0.817 \\
\hline
\end{tabular}

Table 8 implies that the significant $p<0.05$. This indicates that a simple equation model (only constants) has been able to explain the incidence of stunting. Table 8 also provides information about the parameter estimation change model. The results of the summary model test show that the model includes three factors with five variables, including environmental factors with clean water and home sanitation variables, economic factors with family income and food security variables, and social factors with parenting variables. The tests carried out gave the results of changes in parameter estimation (-2 log-likelihood) of 131.217. Meanwhile, the value of $\mathrm{R}$ Square obtained is 0.099 or $9.9 \%$ (Cox and Snell R Square) and 0.154 or $15.4 \%$ (Nagelkerke $\mathrm{R}$ Square). Thus, it can be interpreted that with three factors through 5 variables, the proportion of stunting events is $15.4 \%$. In other words, more proportion of stunting is caused by more factors or variables.

Table 8 also tests the goodness of fit. In principle, this test aims to determine whether a data distribution from the sample has followed a certain theoretical distribution or not, or is also called conformity. This test compares two distributions of data, namely, the theoretical (expected frequency) and the actual (observation frequency). The Goodness of fit test shows that the test results by looking at the Chisquare value have a significance value of $p>0.05$ so it can be concluded that this model has been aligned (fit) in explaining the research data. The last test that was carried out was logistic regression testing to see the effect of the independent variable on the dependent variable. The results of the Logistics Regression test are presented in Table 9.

Table 9: Logistics regression test

\begin{tabular}{lll}
\hline Variables in the equation & & \\
\hline Factor & Variable & Significance \\
\hline Environmental factor & Clean water & 0.915 \\
& House sanitation & 0.049 \\
Economic factor & Family income & 0.080 \\
& Food Security & 0.098 \\
Social factor & Parenting & 0.033 \\
Constants & & 0.000 \\
\hline
\end{tabular}

Table 9 explains that for data analysis using logistic regression, a significance value of $p>0.05$ for the clean water variable is 0.915 . This means that clean water is not a factor causing stunting in the working areas of the three Health Centers. For the second variable, namely, house sanitation from environmental factors, the significance value of $p<0.05$ is 0.049 . This indicates that home sanitation is an important factor as a cause of stunting in the work areas of the three Health Centers. For economic factors, the results show that the two variables, namely family income, and food security, have significant $p>0.05,0.080$, and 0.098 , respectively. In other words, the two variables from economic factors are not a factor causing stunting in the working areas of the three Health Centers. For social factors with variable parenting shows a significance value of $p<0.05$ worth 0.033 which means that the parenting style variable is a factor causing stunting in the work areas of the three Health Centers.

Based on logistic regression statistical testing, it was found that the dominant factor of the five variables showed that only home sanitation and parenting variables affected the incidence of stunting. These results are different from the results of the analysis of the data obtained from interviews, observations, and descriptive statistics. Based on the results of data analysis from interviews, observations, and descriptive statistics, it was found that all variables of the three factors were the main factors in the incidence of stunting in the Kampar watershed.

\section{Conclusion}

This study examines three external factors, including environmental, economic, and social factors. Environmental factors in this study are the variables of clean water and house sanitation. Economic factors include family income and food security variables. Social factors only use parenting variables. The results 
of the logistic regression statistical test showed that the dominant factors for the incidence of stunting from the five variables were home sanitation and parenting patterns. This finding is different from the results of data analysis obtained from interviews, observations, and descriptive statistics. Based on the results of data analysis from interviews, observations, and descriptive statistics, it was found that all variables of the three factors were important factors in the incidence of stunting in children under three who lived in the Kampar watershed.

\section{References}

1. Ivankova NV, Creswell JW, Stick SL. Using mixedmethods sequential explanatory design: From theory to practice. Field Methods. 2006;18(1):3-20. https://doi. org/10.1177/1525822X05282260

2. Ivankova NV, Stick SL. Students' persistence in a distributed doctoral program in educational leadership in higher education: A mixed methods study. Res High Educ. 2007;48(1):93-135. https://doi.org/10.1007/s11162-006-9025-4

3. Creswell JW, Clark VL. Designing and Conducting Mixed Methods Research. housand Oaks, California: Sage Publications; 2017.

4. Kusumawati E, Rahardjo S, Sari HP. Model pengendalian faktor risiko stunting pada anak bawah tiga tahun. Kesmas J Kesehat Masy Nas. 2015;9(3):249-56. http://dx.doi.org/10.21109/ kesmas.v9i3.572

5. Black RE, Victora CG, Walker SP, Bhutta ZA, Christian P, de Onis $M$. Maternal and child undernutrition and overweight in low-income andmiddle-income countries. Lancet. 2013;382(9890):427-51. https://doi.org/10.1016/ S0140-6736(13)60937-X

PMid:23746772

6. Quick R, Turley S, Willekens M. Auditing, trust and governance: Regulation in Europe. ???: ???; 2007. p. 1-283.

7. World Health Organization. Childhood Stunting: Challenges and opportunities. Report of a Promoting Healthy Growth and Preventing Childhood Stunting Colloqium. Geneva: World Health Organization; 2014.

8. Riau RP. Laporan Hasil Riset Kesehatan Dasar Provinsi Riau. Badan Penelitian dan Pengembangan: Dinkes Provinsi Riau; 2019.

9. Torlesse H, Cronin AA, Sebayang SK, Nandy R. Determinants of stunting in Indonesian children: Evidence from a cross-sectional survey indicate a prominent role for the water, sanitation and hygiene sector in stunting reduction. BMC Public Health. 2016;16(1):669. https://doi.org/10.1186/s12889-016-3339-8 PMid:27472935

10. Goodarz D. Evidance on risk factors of stunting. In: School of Public Health. Cambridge, Massachusetts: Harvard University; 2016.

11. Song Y, Agardh A, Ma J, Li L, Lei Y, Stafford RS, et al. National trends in stunting, thinness and overweight among Chinese school-aged children, 1985-2014. Int J Obes. 2019;43(2):40211. https://doi.org/10.1038/s41366-018-0129-7 PMid:29915362

12. Garenne M, Myatt M, Khara T, Dolan C, Briend A. Concurrent wasting and stunting among underfive children in Niakhar,
Senegal. Matern Child Nutr. 2019;15(2):e12736. https://doi. org/10.1111/mcn.12736

PMid:30367556

13. Akombi BJ, Agho KE, Hall JJ, Merom D, Astell-Burt T, Renzaho AM. Stunting and severe stunting among children under-5 years in Nigeria: A multilevel analysis. BMC Pediatr. 2017;17(1):1-16.

14. Wamani H, Åstrøm AN, Peterson S, Tumwine JK, Tylleskär T. Boys are more stunted than girls in sub-Saharan Africa: A metaanalysis of 16 demographic and health surveys. BMC Pediatr. 2007;7(1):17. https://doi.org/10.1186/1471-2431-7-17 PMid: 17425787

15. Biswas S, Bose K. Sex differences in the effect of birth order and parents' educational status on stunting: A study on Bengalee preschool children from eastern India. Homo. 2010;61(4):271-6. https://doi.org/10.1016/j.jchb.2010.03.001

PMid:20619407

16. Candra A, Puruhita N, Susanto JC. Risk factors of stunting among 1-2 years old children in Semarang City. Media Med. 2011;45(3):206-12.

17. Lourenço BH, Villamor E, Augusto RA, Cardoso MA Determinants of linear growth from infancy to school-aged years: A population-based follow-up study in urban Amazonian children. BMC Public Health. 2012;12(1):265.

18. Tomkins AM, Drasar BS, Bradley AK, Williamson WA Water supply and nutritional status in rural northern Nigeria. Trans R Soc Trop Med Hyg. 1978;72(3):196-8. https://doi. org/10.1016/0035-9203(78)90201-8

19. Demarest J, Pagsuyoin S, Learmonth G, Mellor J, Dillingham R. Development of a spatial and temporal agent-based model for studying water and health relationships: The case study of two villages in Limpopo, South Africa. J Artif Soc Soc Simul. 2013;16(4):3. https://doi.org/10.18564/jasss.2169 PMid:25530709

20. Rahmawati VE, Pamungkasari EP, Murti B. Determinants of stunting and child development in Jombang district. J Matern Child Health. 2018;3(1):68-80.

21. Pebriani LV, Jatnika R, Haffas M. Relationship between Parenting Style and Parental Feeding Style in the Locus Stunting Area in West Java. $1^{\text {st }}$ Paris Van Java International Seminar Health Economic Social Science Humanities (PVJ-ISHESSH 2020), Atl Press; 2021. p. 773-76.

22. Aini $Q$, Suhita BM, Anggraini NA. Analysis of factors that influence the stunting event in toddlers in public health center Gandusari Blitar district. J Q Public Health 2020;4(1):242-7.

23. Fadhillah J, Sitti U, Setiawati Y. Studi kasus gaya pengasuhan orang tua terhadap anak batita stunting. Voice of Midwifery 2020;10(1):903-10.

24. Walker S, McGregor SM, Powell CA. Effects of stunting in Early childhood on growth, IQ and cognition at age 11-12 years and the benefits of nutritional supplementation and psychologi calstimulation. J Pediatr. 2000;137(1):36-41. https://doi. org/10.1067/mpd.2000.106227

PMid:10891819

25. Khomsan A, Anwar F, Hernawati N, Suhanda NS, WarsitoO HT. Growth, cognitive development and psychosocial stimulation of preschool childreen inpoor farmer and non farmer households. Mal J Nutr. 2013;19(3):325-37.

26. Perignon $M$, Fiorentino $M$, Kuong $K$, Burja $K$, Parker $M$, Sisokhom S, et al. Stunting, poor iron status and parasite infection are significant risk factors for lower cognitive performance in cambodian school-aged children. PLoS One. 2014;9(11):e112605. https://doi.org/10.1371/journal. pone. 0112605

PMid:25405764 
27. Mamabolo RL, Alberts M, Steyn NP, de Waal HL. Prevalence and determinants of stunting and overweight in 3-year-old black South African children residing in the central region of limpopo Province South Africa. Public Health Nutr. 2005;8(5):501-8. https://doi.org/10.1079/phn2005786

PMid:16153331

28. Erfanti DO, Djatnika SK. The relationship of psychosocial dysfunction and stunting of adolescents in Suburban Indonesia. Open J Med Psychol 2016;5(4):57-65.

29. Nahar B, Hossain M, Mahfuz M, Islam MM, Hossain MI, Kolb LE, et al. Early childhood development and stunting: Findings from the MALED birth cohort study in Bangladesh. Matern Child Nutr. 2020;16(1):e12864.

30. Beal T, Le DT, Trinh TH, Burra DD, Huynh T, Duong TT, et al. Child stunting is associated with child, maternal, and environmental factors in Vietnam. Matern Child Nutr. 2019;15(4):e12826. https://doi.org/10.1111/mcn.12826 PMid:30958643

31. Kwami CS, Godfrey S, Gavilan H, Lakhanpaul M, Parikh P. Water, sanitation, and hygiene: linkages with stunting in rural Ethiopia. Int J Environ Res Public Health. 2019;16(20):3793. https://doi.org/10.3390/ijerph16203793 PMid:31600942

32. Sutarto ST, Mayasari D, Indriyani R. Stunting, Faktor Risiko dan Pencegahannya. Vol. 5. Agromedicine UNILA; 2018.

33. Rahayu RM, Pamungkasari EP, Wekadigunawan CS. The biopsychosocial determinants of stunting and wasting in children aged 12-48 months. J Matern Child Health. 2018;3(2):105-18.

34. Utami RP, Suhartono S, Nurjazuli N, Kartini A, Rasipin R. Faktor Lingkungan dan Perilaku yang Berhubungan dengan Kejadian Stunting pada Siswa SD di Wilayah Pertanian (Penelitian di Kecamatan Bulakamba Kabupaten Brebes). J Kesehat Lingkung Indones. 2013;12(2):127-31.

35. Chambers R, Von Medeazza G. Sanitation and stunting in India: undernutrition's blind spot. Econ Polit Wkly. 2013;48:15-8.

36. Cumming $\mathrm{O}$, Cairncross $\mathrm{S}$. Can water, sanitation and hygiene help eliminate stunting? Current evidence and policy implications. Matern Child Nutr. 2016;12(Suppl 1):91-105. https://doi.org/10.1111/mcn.12258

PMid:27187910

37. Rohmawati N. Risk Factors Stunting Incidence In Children Aged 6-36 Months In Jember Regency. UNEJ e-Proceeding; 2018. p. 128-136.

38. Budiastutik I, Nugraheni SA. Determinants of stunting in Indonesia: A review article. Int J Health Res 2018;1(2):43-9.

39. Phyo SW, Keiwkarnka B, Mongkolchati A. Factors related to stunting status of children aged under two years in Magway township, Myanmar. J Public Health Dev. 2014;12(3):1-16.

40. Custodio E, Descalzo MA, Roche J, Molina L, Sanchez I, Lwanga MT, et al. The economic and nutrition transition in equatorial guinea coincided with a double bur-den of over and under nutrition. Econ Hum Biol. 2010;8(1):80-7. https://doi. org/10.1016/j.ehb.2009.10.001

PMid:19959405

41. Henningham HB, McGregor SG. Gizi dan perkembangan anak. In: Gibney MJ, Margaretts BM, Kearney JM, Arab L, Bahasa A Hartono A, editors. Gizi Kesehatan Masyarakat. Jakarta: EGC. 2009. p. 302-23.

42. Krisnana I, Pratiwi IN, Cahyadi A. The relationship between socio-economic factors and parenting styles with the incidence of stunting in children. Syst Rev Pharm 2020;11(5):738-43. 